
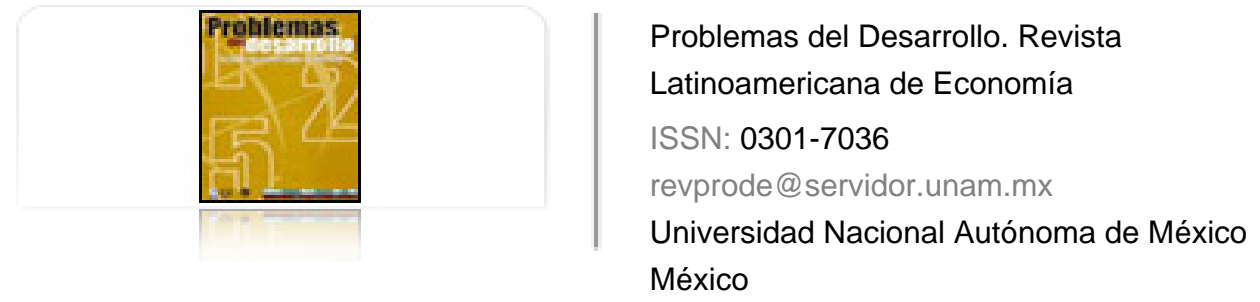

Ramirez, Miguel D.

Foreign Capital and Labor Productivity Growth in Chile: An Empirical Anaysis Problemas del Desarrollo. Revista Latinoamericana de Economía, vol. 36, núm. 140, 2005, pp. 43-61

Universidad Nacional Autónoma de México

Distrito Federal, México

Available in: http://www.redalyc.org/articulo.oa?id=11820092003

How to cite

Complete issue

- More information about this article

Journal's homepage in redalyc.org

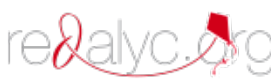

Scientific Information System Network of Scientific Journals from Latin America, the Caribbean, Spain and Portugal Non-profit academic project, developed under the open access initiative 


\title{
Foreign Capital and Labor Productivity Growth in Chile: An Empirical Analysis
}

\section{Miguel D. Ramirez*}

Fecha de recepción: 10 de junio de 2004. Fecha de aceptación: 25 de febrero de 2005.

\begin{abstract}
This paper examines the impact of foreign direct investment (FDI) on labor productivity growth in Chile during the 1960-2001 period. Using co-integration analysis, the paper estimates an error correction model (ECM) that suggests that increases in FDI flows had a positive and significant effect on labor productivity growth. The lagged public investment variable, as well as outward-oriented policies and economic crises (captured by dummies) were also found to have the expected sign and to be statistically significant. The error correction terms are negative and statistically significant, suggesting that contemporaneous shocks to the longrun labor productivity relationship are corrected in subsequent periods.
\end{abstract}

Key terms: error correction model (ECM); akaike information criterion (AIC), and Schwartz bayesian criterion $(S B C)$.

\section{Resumen}

Esta ponencia examina el impacto de la inversión extranjera directa (IED) sobre el crecimiento de la productividad laboral en Chile durante el periodo 1960-2001. Usando el análisis de cointegración, la ponencia estima un modelo de corrección del error (MCE) que sugiere que los aumentos en los flujos de la IED tuvieron un efecto positivo y notable sobre el crecimiento de la productividad laboral. Se encuentra que la variable retrasada de la inversión pública, así como las políticas orientadas hacia afuera y las crisis económicas (capturadas por ficticios), tuvieron el signo esperado y fueron significativos estadísticamente. Los términos de corrección de error son negativos y sugieren que los choques contemporáneos en la relación de productividad laboral de largo plazo son corregidos en periodos subsecuentes.

Palabras claves: modelo de corrección del error (MCE); criterio de información Akaike (CIA); Criterio Schwartz Bayesian (CSB)

\footnotetext{
* Professor of Economics, Trinity College, Hartford. Correo electrónico: ramirez@trincoll.edu
} 


\section{Résumé}

Ce document analyse l'impact de l'investissement étranger direct (sigles en anglais FDI) dans la croissance de la productivité du travail au Chili pendant la période de 1960-2001. En utilisant l'analyse de co-intégration, ce travail étudie un modèle de correction d'erreurs (ECM) qui suggère que la croissance du flux de l'IED (FDI) a un effet positif et signifiant dans la croissance de la productivité du travail. La variable de l'investissement public retardé, aussi bien que les politiques orientées vers l'extérieur et les crises économiques ont aussi montré posséder les signes attendus et être significatifs statistiquement. Les termes de correction d'erreur sont négatifs et statistiquement significatifs, ce qui suggère que les chocs contemporains à la relation de longue durée de la productivité du travail se corrigent lors des périodes suivantes.

Mots clés: modèle de correction d'erreur (MCE) ; critère d'information Akaike (AIC), et critère Schwartz Bayesian (CSB).

\section{Resumo}

Este documento estuda o impacto do investimento estrangeiro direto (IED) sobre o crescimento da produtividade laboral no Chile durante o período 1960-2001. Mediante um análise de cointegração, o estudo percebe um modelo de correção de erros (MCE) que sugere que os incrementos nos fluxos do IED tiveram um efeito positivo e importante no crescimento da produtividade laboral. Tanto a variável atrasada no investimento público quanto as políticas externas e crises económicas (capturadas por principiantes) também tiveram o sinal esperado e foram estatisticamente relevantes. Os termos de correção de erros são negativos e relevantes estatisticamente, e sugerem que os choques contemporaneos contra o relacionamento da produtividade laboral ao longo prazo corrigem-se em períodos subseqüentes.

Palavras chave: modelo de correção de erros (MCE), critério Akaike de informação (CAI) e critério Schwartz Bayesian (CSB). 


\section{Introduction}

I

$\mathrm{n}$ recent years, foreign direct investment (FDI) undertaken by transnational corporations

(TNCS) has become one of the leading factors in promoting the process of economic

globalization. For example, between 1985 and 1990 these flows averaged just \$142

billion on an annual basis, while during the 1990-99 period alone they averaged $\$ 270$

billion, or almost twice as much [see Economic Commission for Latin America and the

Caribbean (ECLAC), 2001]. The surge in FDI flows during the 1990s was also characterized by an increasing proportion of these funds directed towards the developing nations, including the countries of Latin America and the Caribbean. For example, the share of total FDI channeled to developing countries, particularly in Asia and Latin America, rose from 14 percent in 1990 to 24 percent in 1999. Latin America's share of FDI flows to developing countries rose from 29 percent in 1995 to 37 percent in 1999, mainly confined to Argentina, Brazil, Chile and Mexico (ECLAC, 2001).

In relative terms, the major countries of Latin America, particularly Chile, exhibited a consistently strong record of attracting FDI inflows during the decade of the 1990s, never falling below 1.5 percent of their countries' respective GDPs, and beginning in 1994, FDI inflows have averaged 5.4 percent in the case of Chile (ECLAC, 2001). More importantly, FDI flows relative to Chile's gross fixed capital formation during the 1990-1995 period represented close to 10 percent of its gross fixed capital formation, and in 1996 and 1997, these flows reached more than a quarter of gross fixed capital formation - the highest figure among the major countries of the region, or for that matter, the developing world (see ECLAC, 2001). ${ }^{1}$

However, critics of FDI contend that instead of increasing the capital resources of the host nation, FDI flows represent a net drain on the country's scarce resources because they

1 A reviewer has correctly pointed out that it may be misleading to relate FDI to fixed capital formation since FDI is a capital flow that includes both the creation of new plant, machinery, and equipment, as well as the purchase of existing assets via mergers and acquisitions. In the case of Chile, up until 1995 most of the FDI entering the country (particularly via Chapters XIX and Decree Law 600) was destined towards new fixed investment, while during the 1996 2001 period, a higher percentage has been channeled towards mergers and acquisitions in electricity, gas, and water (27\%), telecommunications (8\%) and financial and banking services (20\%) (see ECLAC, 2002). In defense of this widely used practice in the literature two arguments are advanced. First, as the figures attest, not all FDI was directed towards the acquisition of existing assets. And second, to the extent that FDI is directed toward the acquisitions of existing assets, it may generate a positive externality to the economy if the new owners introduce new technology and more efficient managerial practices (see endnote 2 below).

\section{DeSarrollo}


generate substantial reverse flows in the form of remittances of profits and dividends to the parent companies, as well as through the widespread practice of intra-firm transfer pricing (see Cypher and Dietz, 1997; and Plasschaert, 1994). In this connection, for Latin America as a whole, profit and dividend remittances to the developed countries more than tripled between 1990 and 2000, from $\$ 7.0$ billion to over $\$ 25$ billion (see ECLAC, 2001). Chile's remittances of profits and dividends registered more than a sevenfold increase between 1990 and 2000, from $\$ 335$ million to $\$ 2.4$ billion, and they averaged 52 percent of total FDI flows over the 1990-2000 period.

Economic theory, however, suggests that rather than focus on the flows of FDI to the countries of Latin America, it is theoretically more appropriate to concentrate on the accumulated stock of FDI, because it is the latter that ultimately determines the marginal productivity of private capital (and labor). The stock of FDI in Latin America (1990 dollars) rose from $\$ 175.6$ billion in 1990 to $\$ 466.9$ billion in 2000 . This represents almost a doubling in the stock of FDI of these countries, an increase which is far greater than that of the entire lost decade of the 1980s. Chile's stock of FDI rose from \$12.3 billion in 1990 to an impressive level of $\$ 26.8$ billion by year-end 1999 . Endogenous growth theory suggests that if this accumulation of capital in the form of FDI has generated substantial spillover benefits, both of an indirect and direct nature as explained below, then the long-term positive contribution of this surge in FDI during the decade of the 1990s cannot be adequately measured by focusing solely on flow variables.

In view of the controversy surrounding this important topic, this paper examines the impact of FDI flows on labor productivity growth in one of the more economically successful countries of Latin America: Chile. It was one of the earliest countries in the region to adopt and implement market-based reforms, albeit at great social and political cost. The country began this process of economic and financial liberalization following the military coup of 1973 and, in recent years, it has further liberalized its FDI regime by modifying Decree Law 600 and its debt capitalization mechanism (Chapter XIX of the Central Bank's International Exchange Compensation Regulations). FDI flows into Chile have been mainly channeled to traditional sectors such as mining and energy sectors. However, during the first half of the nineties, a significant proportion of these funds was channeled to exportoriented manufacturing operations (so-called greenfield sectors) using innovative technological processes and managerial techniques. The second half of the decade witnessed an increasing share of FDI directed towards the merger and acquisition of existing firms, but this too may lead to a positive externality if the new owners, via a demonstration (learning-by-doing) effect, introduce new technologies and better managerial practices that are then adopted by competing firms. ${ }^{2}$ An analysis of FDI flows to Chile during the

2 In this connection, significant spill over learning effects in agriculture are reported in a study by Foster and Rosenzweig (1995) because "farmers with experienced neighbors [who have introduced 
decade of the nineties should therefore uncover important trends and provide valuable insights into the capacity of FDI to transfer up-to-date technology and managerial knowhow, as well as its long-term effect on labor productivity growth.

The paper is organized as follows: First, it motivates the empirics by presenting a simple dynamic endogenous growth model that explicitly incorporates FDI's potential impact on private capital formation and labor productivity growth. The following section presents an empirical counterpart to the theoretical model developed in the previous section and discusses the data used in this study. Using co-integration analysis, section IV assesses the impact of percentage changes in the stock of FDI on average labor productivity growth during the 1960-2001 period. The last section summarizes the major arguments and offers some policy prescriptions for attracting FDI into the region and enhancing its positive direct and indirect effects.

\section{The Model}

FDI inflows into developing countries have the potential of increasing their stock of capital per worker and technological and managerial know-how which, in turn, raises the host country's level of output, labor productivity, and tax revenues (see De Mello, Jr., 1997; and Zhang, 2001). However, FDI flows may have a negative effect on the growth prospects of a country if they give rise to substantial reverse flows in the form of remittances of profits and dividends and/or if TNCs bring to the country technologies that are inappropriate for the host country's factors of production (e.g., technology that is too capital intensive). These negative effects may be further compounded if the expected positive spillover effects from the transfer of more advanced technology are minimized or eliminated because of overly restrictive intellectual property rights and/or prohibitive royalty payments and leasing fees charged by the TNCs for the use of these intangibles (see Cypher and Dietz, 1997; and Ram and Zhang, 2002).

Following the lead of Sanchez-Robles (1997), De Mello, Jr. (1997), and Roubini and Sala-i-Martin (1992), we develop a simple endogenous model that incorporates the externality (positive or negative) associated with the presence of FDI. It can be explicitly modeled with a Cobb-Douglas production function in per capita terms of the following form:

$$
\mathrm{y}=\varphi\left(\mathrm{k}_{\mathrm{f}}\right) \mathrm{k}^{\beta}, \varphi=\left(\mathrm{k}_{\mathrm{f}}\right) \stackrel{\geq}{<} 0
$$

high yield seed varieties] are significantly more profitable than those with inexperienced neighbors"(1205).

\section{DeSarrollo}


where $y$ is real per capita output, $k$ denotes the stock of physical (domestic) capital per capita, and $\varphi\left(k_{f}\right)$ captures the externality generated by additions to the stock of FDI capital. $\beta$ represents the share of private domestic capital per capita. It is also assumed that $\beta$ is less than one, such that there are diminishing returns to private domestic capital per worker; i.e., each additional unit of private domestic capital that we give to a single worker increases the output of that worker by less and less.

The externality, $\varphi\left(k_{f}\right)$, can be represented in the following way:

$$
\varphi\left(\mathrm{k}_{\mathrm{f}}\right)=\mathrm{ak}^{\theta}
$$

where a is some positive constant ${ }^{3}$ and $\theta$ is a parameter designed to capture the effect of foreign capital on the domestic economy. If $\theta>0$, then additions to the stock of foreign capital over time imply a larger stock of domestic capital which, in turn, generates a positive knowledge externality to the economy, while if $\theta<0$, FDI generates a negative externality over time and diminishes the growth potential of the host country. Examples of positive knowledge externalities are the gains in efficiency generated by the transfer of more technologically advanced capital equipment and superior managerial practices, while negative externalities may take the form of the transfer of inappropriate technology relative to the host country's factor endowments, substantial remittances of profits and dividends, and the demise of domestically-owned enterprises as a result of the formidable monopoly power of TNCs that bring FDI (see De Mello, Jr., 1997; Ram and Zhang, 2002; and Zhang, 2001).

Combining equations (1) and (2), we obtain,

$$
\mathrm{y}=\mathrm{ak}^{\theta} \mathrm{k}^{\beta}
$$

The production function in (3) will be homogenous of degree 1 in $k$, and therefore display endogenous growth, provided that $\theta+\beta=1$. Before turning to the competitive solution, it is assumed that the economy produces one good that can be devoted to consumption or investment. The economy's rate of capital accumulation in per capita terms can therefore be represented by the standard equation given below.

$$
\dot{k}=\mathrm{y}-\mathrm{c}-\delta \mathrm{k}
$$

where $c$ is per capita consumption and $\delta$ denotes the constant rate of depreciation.

3 It is conventional to assume that the FDI induced externality is proportional to the amount of capital per worker, rather than exactly equal to it, i.e., if $a=1$.

\section{DeSarrollo}




\section{Competitive Solution}

Representative agents in the economy attempt to maximize over time the present value of a standard concave utility function given in equation (5) below:

$$
\begin{aligned}
& \operatorname{Max} \mathrm{u}(\mathrm{t})=\int_{0}^{\infty} \mathrm{e}^{-\mathrm{pt}} \mathrm{u}[\mathrm{c}(\mathrm{t})] \mathrm{L}(\mathrm{t}) \mathrm{dt} \\
& \text { s.t. } \dot{k}=\mathrm{ak}^{\theta} \mathrm{k}^{\beta}-\mathrm{c}-\delta \mathrm{k}, \mathrm{k}(0) \exists 0,
\end{aligned}
$$

where, again, for convenience, lower case letters are defined in per capita terms and $\rho$ is the discount rate; $L(t)$ is the size of the family; $c(t)$ is per capita consumption, and a dot over the variable denotes the derivative with respect to time. For simplicity, the initial population is normalized to 1 so that the analysis in aggregate terms and per capita terms is the same. The instantaneous utility function of the representative (infinite lifetime) consumer is assumed to exhibit constant relative risk and can be written in the general form:

$$
\mathrm{u}[\mathrm{c}(\mathrm{t})]=\left[\mathrm{c}(\mathrm{t})^{1-\sigma}-1\right] / 1-\sigma
$$

where $\sigma$ denotes the relative risk-aversion coefficient or the inverse of the elasticity of substitution between current and future consumption; that is, $\sigma$ is an index of the representative consumer's willingness to trade off current consumption for future consumption. To solve the inter-temporal utility maximization problem we construct the current Hamiltonian value:

$$
\mathrm{H}=\left[\mathrm{c}(\mathrm{t})^{1-\sigma}-1\right] / 1-\sigma+\lambda\left[\mathrm{ak}^{\theta} \mathrm{k}^{\beta}-\mathrm{c}-\delta \mathrm{k}\right]
$$

Taking derivatives of equation (7) with respect to $\mathrm{c}$ and private (domestic) capital, $k$, we obtain the following first order conditions:

$$
\begin{gathered}
\mathrm{H}_{\mathrm{c}}=0 \varpi \mathrm{c}^{-\sigma}=\lambda \\
\rho \lambda-\mathrm{H}_{\mathrm{k}}=\dot{\lambda} \varpi \rho \lambda-\lambda \mathrm{a} \beta \mathrm{k}^{\theta+\beta-1}+\lambda \delta=\dot{\lambda}
\end{gathered}
$$

Together equations (8), (9) and the transversality condition, ${ }_{t \rightarrow \infty}^{\operatorname{Lim}} \lambda(t) k(t)=0$, are referred to as the canonical system for the given problem. Taking logs in (8), differentiating with respect to time, and inserting (9) we obtain the following dynamic equation:

$$
\dot{c} / \mathrm{c}=(1 / \sigma)\left[a \beta k^{\theta+\beta-1}-\rho-\delta\right]
$$

Equation (10) shows that in the presence of an inter-temporal positive externality between foreign and private capital $(\theta>0)$, the marginal product of capital, net of

\section{DeSarrollo}


depreciation, is augmented and kept above the discount rate of the representative agent by additions to the stock of foreign capital. In the case where the production function is homogeneous of degree $1(\theta+\beta=1)$, then equation (10) becomes:

$$
\dot{c} / \mathrm{c}=(1 / \sigma)[\mathrm{a} \beta-\rho-\delta]
$$

This shows that, in the presence of a FDI-induced knowledge externality, additional units of capital are no less effective than prior increments in sustaining a non-decreasing rate of steady-state consumption and output per capita. Put differently, diminishing returns to private domestic capital are avoided entirely as a result of the society-wide knowledge externality generated by the superior technology and managerial know-how embodied in additional units of FDI capital. Of course, if additional units of foreign capital generate a negative externality $(\theta<0)$, then the presence of foreign capital will magnify diminishing returns to private domestic capital and additional units of capital will become progressively less and less effective in sustaining the economy's steady-state growth rate of output and consumption per capita.

\section{Empirical Model}

For simplicity, the economic effect of FDI on the Chilean economy is tested via the estimation of a modified Cobb-Douglas production function during the1960-2001 period under the assumption of constant returns to scale. (The appendix describes the data sources and the methodology used to calculate the capital stock series.) After taking logs and differences in the variables, the most general formulation of the dynamic production function in per worker terms is given below:

$\Delta \mathrm{y}_{\mathrm{t}}=\alpha+\beta_{1} \Delta \mathrm{k}_{\mathrm{p}, \mathrm{t}-\mathrm{i}}+\beta_{2} \Delta \mathrm{k}_{\mathrm{f}, \mathrm{t}-\mathrm{i}}+\beta_{3} \Delta \mathrm{k}_{\mathrm{g}, \mathrm{t}-\mathrm{i}}+\beta_{4} \mathrm{D}_{1}+\beta_{5} \mathrm{D}_{2}+\beta_{6} \mathrm{D}_{3}+\beta_{7} \Delta \mathrm{TOT}+\varepsilon$

Lower case letters denote natural logarithms, $\Delta$ is the difference operator, and i denotes the lag lengths; y represents the natural log of real GDP per worker (1977 pesos); $\Delta y_{t}$ is the labor productivity growth rate and it is defined as, $(\Delta \ln Y-\Delta \ln L) ; k_{p}, k_{f}$ and $k_{g}$ denote, respectively, the natural log of the stocks of private capital per worker, FDI capital per worker, and public capital per worker (1977 pesos); $\Delta k_{p}$ is the growth rate in the private capital stock per worker and is defined as $\left(\Delta \ln K_{p}-\Delta \ln L\right)$, and likewise for the other variables in factor-intensive form; $D_{1}$ is a dummy variable that equals 1 for the crises years of 1973 (military coup), 1975 (major economic recession), 1982-1983 (major economic recession) and 0 otherwise, while $D_{2}$ equals 1 for the debt-led growth years of 1978-1981; and $D_{3}$ is set equal to 1 for the 1987-1997 period (acceleration of real economic growth associated with the Chilean government's decision to pursue vigorously an outward-

\section{DêSarrortollo}


oriented strategy of economic development beginning in 1986-1987). Given the historical (and continuing importance) of copper exports to the Chilean economy, the regression also includes a terms of trade variable, $\triangle T O T$, which is defined as the percentage change in the terms of trade. An increase in $\triangle T O T$ denotes an improvement in Chile's terms of trade (see Ffrench-Davis and Munoz, 1992).

The model was also estimated with an interactive dummy variable for the post-1995 period, viz., $D 4$ multiplied by the lagged FDI growth variable. By estimating this variable interactively with the FDI variable one can (crudely) assess whether the recent change in the composition of FDI towards operations in energy, telecommunications, manufacturing, and financial services has led to greater output (labor productivity) growth. ${ }^{4}$ A finding that it has would be consistent with the notion that changes in the mix of FDI to higher valued-added operations has led to greater positive spillover effects.

The coefficients of equation (11) represent the annual percentage change in labor productivity growth associated with a respective change in the growth rate of the variables in per worker terms. $\beta_{1}$ is expected to be positive, while the signs of $\beta_{2}$ and $\beta_{3}$ can be either positive or negative depending on whether changes in the stocks of foreign and public capital, respectively, complement or substitute for private capital formation. The public capital stock variable was included as an argument because investments in economic infrastructure such as roads, bridges and ports are likely to increase the marginal productivity of both private domestic and foreign capital, thus stimulating economic growth and labor productivity. ${ }^{5}$ It is anticipated that $\beta_{4}$ will have a negative sign for obvious reasons. $\beta_{5}$ is expected to be positive because of the high rates of economic growth associated with the short-lived lending boom of 1978-1981. $\beta_{6}$ is also expected to have a positive sign because the average annual growth rate in Chile accelerated with the return of foreign direct investment and the expansion of exports during the 1988-1994 period. Finally, $\beta_{7}$ is expected to have a positive sign because an improvement in the TOT variable, ceteris paribus, stimulates economic growth in an open economy such as the Chilean one. ${ }^{6}$

4 During 1996 2000 Chile experienced a marked decline in the proportion of FDI channeled to the mining and agricultural sectors (25\%) and a dramatic increase in the share allocated to telecommunications, manufacturing, energy, and financial services (75\%). The FDI flows destined to the manufacturing sector were primarily in the form of minority shares in leading industrial sectors, while those flows directed to the financial services sector involved majority acquisitions of existing assets such as Spain's Banco Santander's 51 percent stake in Banco Osorno for $\$ 500$ million (see ECLAC, 2001).

5 There is now a vast literature that addresses the question of whether public investment enhances private investment and economic growth. The results have been mixed, with some researchers finding support for the complementarity hypothesis while others reject it (see Aschauer, 1990; Cardoso, 1993; Cruz and Teixera, 1999; and Ramirez, 2000).

6 The government consumption variable was not included in the estimation because not only does it include human capital investments such as expenditures on health and education (which are likely to enhance labor productivity), but also a substantial portion is devoted to expenditures on public 


\section{Co-integration Analysis and Results}

Time-series data such as the ones used in this study tend to exhibit either a deterministic and/or stochastic time trend and are therefore non-stationary. Engle and Granger (1987) have shown that regressing a non-stationary series against another one may lead to spurious results because conventional significance tests are likely to suggest that a relationship exists when, in fact, there is none. Unit root (non-stationarity) tests were undertaken by using an Augmented Dickey-Fuller test (ADF) (Dickey-Fuller, 1981) with a constant (representing positive or negative drift) and a deterministic trend (representing a nonstationary mean).

Part A of Table 1 presents the results of running an ADF test (one lag) for the variables in both level and differenced form under the assumption of a stochastic trend with drift only. It can be readily seen that all the variables in level form are non-stationary; i.e., they appear to follow a stochastic trend with (positive) drift (see Nelson and Plosser, 1982). ${ }^{7}$ In first differences, however, the null hypothesis of non-stationarity is rejected for all variables (except one) at least at the 5 percent level. ${ }^{8}$

Part B of Table1 presents the results of running an ADF test (one lag) on the variables in logarithmic form with a deterministic trend. ${ }^{9}$ The results indicate that the null hypothesis of non-stationarity cannot be rejected for any of the variables in level form with a deterministic trend, suggesting that the variables in question do appear to exhibit a nonstationary (time-dependent) mean throughout the period under review. In other words, detrending the data by a single trend line will not render the data in question stationary because the trend line itself may be shifting over time (see Charemza and Deadman, 1997). However, not all of the variables become stationary in first differences at the five percent level of significance (two are not significant and one is significant at the 10 percent level). Thus, the evidence presented above suggests that the variables in question follow primarily a stochastic trend with (upward) drift as opposed to a deterministic one, although the possibility that for given sub-periods they follow a mixed process cannot be rejected.

wages and salaries (which are likely to have a negative effect). The available data from the Central Bank of Chile is not sufficiently disaggregated to generate a human capital variable via the perpetual inventory model.

$7 \quad$ A stochastic trend is one where the random component of the series itself, say variable $x_{t}$, contributes directly to the long run pattern of the series, either upward or downward. However, in the case of a deterministic trend the deviations from the non stationary mean are quickly corrected over time (see Charemza and Deadman, 1997).

8 This study also performed unit root tests on the relevant variables using the Phillips $\sim$ Perron (PP) test regression. The results (available upon request) are consistent with those generated by the ADF test. See Phillips and Perron (1988) for further details.

9 The order of the lag length was determined by applying both the Akaike Information Criterion (AIC) and the Schwartz Bayesian Criterion (SBC). Lower values for these performance statistics indicate a better fit to the data.

\section{Desarrollo}


FOREIGN CAPITAL AND LABOR PRODUCTIVITY GROWTH IN CHILE

Table 1

Part A: Chile: Unit Root Tests for Stationarity with constant only, Sample Period 1960-2001

\begin{tabular}{ccccc}
\hline Variables & Levels & First Difference & 5\% Critical Value & 1\% Critical Value \\
\hline $\ln (\mathrm{Y})$ & 0.26 & $-3.99^{* * *}$ & -2.93 & -3.61 \\
$\ln (\mathrm{Y})$ & 0.26 & $-3.99^{* * *}$ & -2.93 & -3.61 \\
$\ln _{\mathrm{f}}$ & 0.98 & $-2.91^{*}$ & -2.93 & -3.61 \\
$\ln _{\mathrm{p}}$ & 0.32 & $-3.24^{* *}$ & -2.93 & -3.61 \\
$\operatorname{lnK}_{\mathrm{g}}$ & -0.63 & $-3.71^{* * *}$ & -2.93 & -3.61 \\
$\mathrm{y}$ & -0.88 & $-3.92^{* * *}$ & -2.93 & -3.61 \\
$\mathrm{k}_{\mathrm{f}}$ & 0.77 & $-2.90^{*}$ & -2.93 & -3.61 \\
$\mathrm{k}_{\mathrm{p}}$ & -0.10 & $-3.46^{* * *}$ & -2.93 & -3.61 \\
$\mathrm{k}_{\mathrm{g}}$ & -2.22 & $-3.88^{* * *}$ & -2.93 & -3.61 \\
$\mathrm{TOT}$ & -1.65 & $-5.32^{* * *}$ & -2.93 & -3.61 \\
\hline
\end{tabular}

Part B. Chile: Unit Root Tests for Stationarity with constant and time trend, Sample Period 1960-2001

\begin{tabular}{|c|c|c|c|c|}
\hline Variables & Levels & First Difference & $5 \%$ Critical Value $^{2}$ & $1 \%$ Critical Value \\
\hline $\ln (Y)$ & -1.44 & $-4.08 * * *$ & -3.53 & -4.21 \\
\hline $\ln (\mathrm{L})$ & 1.65 & $-3.96 * * *$ & -3.53 & -4.21 \\
\hline $\ln \mathrm{K}_{\mathrm{f}}$ & -1.47 & $-3.37 *$ & -3.53 & -4.21 \\
\hline $\operatorname{lnK}_{\mathrm{p}}^{1}$ & -2.94 & $-3.22 * *$ & -3.53 & -4.21 \\
\hline $\ln K_{g}^{p}$ & -1.97 & -3.00 & -3.53 & -4.21 \\
\hline$y^{-g}$ & -1.01 & $-4.02 * *$ & -3.53 & -4.21 \\
\hline $\mathrm{k}_{\mathrm{f}}$ & -1.22 & $-3.27 *$ & -3.53 & -4.21 \\
\hline $\mathrm{k}_{\mathrm{n}}^{\mathrm{t}}$ & -2.61 & $-3.50 *$ & -3.53 & -4.21 \\
\hline $\mathrm{k}_{\mathrm{g}}^{\mathrm{p}}$ & -2.25 & -2.96 & -3.53 & -4.21 \\
\hline TÖ & -2.21 & $-4.87 * * *$ & -3.53 & -4.21 \\
\hline
\end{tabular}

1 MacKinnon critical values for rejection of hypothesis of a unit root. *, **, and *** denote significance at the 10,5 and 1 percent levels, respectively.

2 Same as above.

The well-known Johansen (1988) method was used to determine whether the I(1) variables have a stable and non-spurious (co-integrated) relationship in level form in each of the relevant specifications. The necessity arises because applying first differences to the logarithms of the variables in question leads to a loss of information regarding the longrun properties of the estimated model; i.e., a model evaluated in difference form is wrongly specified because it does not have a long-run solution. The Johansen method was chosen over the one originally proposed by Engle and Granger (1987) because it is capable of determining the number of co-integrating vectors for any given number of non-stationary series (of the same order), its application is appropriate in the presence of more than two variables, and more important, Johansen (1988) has shown that the likelihood ratio tests used in this procedure (unlike the DF and ADF tests) have well-defined finite sample distribution. ${ }^{10}$

10 Admittedly, the relatively small sample size used in this study (between 35 and 39 observations after adjusting for endpoints) obviates the need to discuss the asymptotic properties of large sample

\section{DeSarrollo}


MIGUEL D. RAMIREZ

Table 2

Chile: Johansen Cointegration (Trace) Test, 1960-2001

\begin{tabular}{|c|c|c|c|c|c|}
\hline \multicolumn{6}{|c|}{$\begin{array}{l}\text { A. Series: } y, k_{f}, k_{g} \text {, and } K_{p} \\
\text { Test assumption: No deterministic trend in the data }\end{array}$} \\
\hline Eigenvalue & \multicolumn{2}{|c|}{ Likelihood Ratio } & $5 \%$ & $1 \%$ & No. of $C E(s)$ \\
\hline 0.727 & \multicolumn{2}{|c|}{94.014} & 62.99 & 70.05 & None \\
\hline 0.548 & \multicolumn{2}{|c|}{48.487} & 42.44 & 48.45 & At most 1 \\
\hline 0.340 & \multicolumn{2}{|c|}{20.679} & 25.32 & 30.45 & At most 2 \\
\hline \multicolumn{6}{|c|}{ B. Normalized Cointegrating Vector; coefficients normalized on y in parenthesis } \\
\hline Vector & $y$ & $k_{f}$ & $k_{p}$ & $k_{g}$ & Constant \\
\hline 1. & 1.000 & $\begin{array}{l}-0.045 \\
(2.674)\end{array}$ & $\begin{array}{l}-0.310 \\
(7.739)\end{array}$ & $\begin{array}{c}-0.481 \\
(17.190)\end{array}$ & $\begin{array}{l}-1.700 \\
(1.721)\end{array}$ \\
\hline
\end{tabular}

Note: t-ratios are in parenthesis. Signs are reversed in the cointegrating vector because of the normalization process.

Table 2 below reports the trace statistics for the Johansen co-integration test and they suggest that the hypothesis of no co-integrating vector can be rejected at least at the one percent level, thus suggesting the presence of at least one co-integrating equation from which residuals (EC terms) can be obtained to measure the respective deviations between the current level of labor productivity and the level based on the long-run relationship. ${ }^{11}$ The table also reports the long-run co-integrating vector (in level form) and the estimates have the expected signs and are statistically significant at least at the five percent level. For example, a ceteris paribus 10 percent increase in the foreign capital stock per worker raises output per worker by an estimated 0.45 percent in the long run. The presence of a co-integrating relationship among the selected variables in level form means that an error correction (EC) model can be estimated; viz., a model that combines both the short-run properties of economic relationships in first difference form as in equation (11) above, as well as the long-run information provided by the data in level form. EC models thus enable the researcher to estimate the speed of adjustment back to the long-run (stable) condition among the variables.

The information provided by the Johansen test was used to generate the EC models presented in Table 3 below. They show that the immediate impact of changes in the growth rate of the private capital stock per worker are positive and statistically (and

estimators. Still, the sample $\sim$ size is sufficiently large (greater than 30 ) to allow us to invoke the Central Limit Theorem and use the Johansen likelihood ratio test. In addition, the Johansen method is employed because there are more than two integrated variables of the same order in the various estimated regressions.

11 The max eigenvalue test also indicated the presence of one co-integrating vector at the one percent level of significance, and two co-integrating vectors at the 5 percent level.

\section{Desarrollo}


Table 3

Chile: Error Correction Model;

Dependent Variable is: $\Delta y_{t}=\left(\Delta \ln Y_{t}-\Delta \ln L_{t}\right), 1960-2001$

\begin{tabular}{|c|c|c|c|c|c|}
\hline \multirow[b]{2}{*}{ Variables } & \multicolumn{5}{|c|}{ oLs Regressions } \\
\hline & (1) & (2) & (3) & (4) & (5) \\
\hline Constant & $\begin{array}{l}-2.99 \\
(-1.87) * *\end{array}$ & $\begin{array}{c}-0.76 \\
(-0.61)\end{array}$ & $\begin{array}{l}-1.95 \\
(-1.58)^{*}\end{array}$ & $\begin{array}{l}-2.04 \\
(-1.66)^{*}\end{array}$ & $\begin{array}{c}-0.75 \\
(-0.64)\end{array}$ \\
\hline$\Delta \mathrm{k}_{\mathrm{ft}-5}$ & $\begin{array}{l}0.17 \\
(2.20)^{* *}\end{array}$ & $\begin{array}{l}0.13 \\
(1.96)^{* *}\end{array}$ & $\begin{array}{l}0.10 \\
(2.13)^{* *}\end{array}$ & $\begin{array}{l}0.10 \\
(1.96)^{* *}\end{array}$ & $\begin{array}{c}0.10 \\
(2.04)^{* *}\end{array}$ \\
\hline DUM4 $*\left(\Delta \mathrm{k}_{\mathrm{ft}-5}\right)$ & - & - & - & - & $\begin{array}{l}0.13 \\
(1.70)^{* *}\end{array}$ \\
\hline$\Delta \mathrm{k}_{\mathrm{pt}}$ & $\begin{array}{l}0.69 \\
(6.13)^{* * *}\end{array}$ & $\begin{array}{l}0.44 \\
(4.24)^{* * *}\end{array}$ & $\begin{array}{l}0.49 \\
(5.01) * * *\end{array}$ & $\begin{array}{l}0.44 \\
(4.61)^{* * *}\end{array}$ & $\begin{array}{l}0.44 \\
(4.30)^{* * *}\end{array}$ \\
\hline$\Delta \mathrm{k}_{\mathrm{gt}-3}$ & $\begin{array}{l}0.29 \\
(2.06)^{* *}\end{array}$ & $\begin{array}{l}0.33 \\
(3.50)^{* * *}\end{array}$ & $\begin{array}{l}0.34 \\
(4.04)^{* * *}\end{array}$ & $\begin{array}{l}0.37 \\
(4.17)^{* * *}\end{array}$ & $\begin{array}{l}0.34 \\
(3.72)^{* *}\end{array}$ \\
\hline Ect $_{t-1}$ & $\begin{array}{l}-0.57 \\
(-3.92)^{* * *}\end{array}$ & $\begin{array}{l}-0.30 \\
(-1.90)^{* *}\end{array}$ & $\begin{array}{l}-0.44 \\
(-3.21)^{* * *}\end{array}$ & $\begin{array}{l}-0.36 \\
(-2.47)^{* * *}\end{array}$ & $\begin{array}{l}-0.27 \\
(-1.98) * * *\end{array}$ \\
\hline DUM1 & - & $\begin{array}{l}-6.02 \\
(-2.86) * *\end{array}$ & $\begin{array}{l}-4.75 \\
(-3.68) * * *\end{array}$ & $\begin{array}{l}-5.39 \\
(-3.19) * * *\end{array}$ & $\begin{array}{l}-5.81 \\
(-2.88) * * *\end{array}$ \\
\hline DUM2 & - & - & $\begin{array}{l}2.86 \\
(3.90) * * *\end{array}$ & $\begin{array}{l}3.09 \\
(3.14)^{* * *}\end{array}$ & - \\
\hline DUM3 & - & - & - & $\begin{array}{l}1.59 \\
(1.81)^{* * *}\end{array}$ & - \\
\hline$\Delta \mathrm{TOT}$ & $\begin{array}{l}0.26 \\
(2.37) * *\end{array}$ & $\begin{array}{l}0.23 \\
(2.30)^{* *}\end{array}$ & $\begin{array}{l}0.22 \\
(2.40) * * *\end{array}$ & $\begin{array}{l}0.19 \\
(1.96)^{* *}\end{array}$ & $\begin{array}{l}0.24 \\
(2.42)^{* *}\end{array}$ \\
\hline Adj $R^{2}$ & .65 & .73 & .76 & .76 & .75 \\
\hline S.E. & 3.41 & 3.18 & 2.82 & 2.84 & 3.20 \\
\hline D.W. & 1.93 & 1.87 & 1.80 & 1.84 & 1.85 \\
\hline $\operatorname{AR}(1)$ & $0.41 *$ & $0.34 *$ & $0.40 * *$ & $0.36 *$ & $0.36 * *$ \\
\hline Sample size & 42 & 42 & 42 & 42 & 42 \\
\hline
\end{tabular}

Note: Asterisks are defined as in Table 3. AR(1) refers to a first order auto-regressive specification and t-ratios are in parenthesis.

economically) significant. The growth rate in the public capital stock per worker variable also has a positive and statistically significant effect when lagged two to three periods. Turning to the foreign private capital stock per worker variable, it can be seen that the growth rate in this variable has a positive and statistically significant effect when lagged four or five periods. This result —as well as the one for the public capital stock — is not

\section{DeSarrollo}


surprising because FDI-induced positive externalities, in the form of a greater transfer of technology and managerial know-how (or investments in transportation and communication) are likely to impact labor productivity with a considerable lag. More importantly, the estimate for the interaction variable ( $D 4$ multiplied by the FDI variable) in equation (5) suggests that the sectoral change in the composition of FDI after 1995 had the effect of further enhancing the impact of FDI growth on labor productivity growth.

The remaining dummy variables in equations (2) -(5) have the anticipated signs and they are statistically significant, while, as expected, the change in the terms of trade effect has a positive and statistically significant effect. The relative fit and efficiency of the EC regressions is quite good and, as the theory predicts, the EC terms are negative and statistically significant, suggesting, as in equation (4), Table 3, that a deviation from long-run labor productivity growth in a given year is corrected by about 36 percent in the next year. Finally, stability tests were undertaken to determine whether the null hypothesis of no structural

Table 4

Chile: In-Sample Forecast Evaluation for Error Correction Models

\begin{tabular}{lcc}
\hline & Equation (3) & Equation (4) \\
\hline Sample: 1967-2001 & & \\
Root Mean Squared Error (RMS) & 2.3855 & 2.2165 \\
Mean Absolute Error (MAE) & 1.7691 & 1.6628 \\
& & \\
Theil Inequality Coefficient (TIC) & 0.2108 & 0.2015 \\
Bias Proportion (BP) & 0.0000 & 0.0000 \\
Variance Proportion (VP) & 0.0011 & 0.0331 \\
Covariance Proportion (CP) & 0.9988 & 0.9668 \\
Sample: 1967-1995 & & \\
RMS & & \\
MAE & 2.7200 & 2.3504 \\
TIC & 2.1189 & 1.8777 \\
BP & 0.2276 & 0.2004 \\
VP & 0.0002 & 0.0000 \\
CP & 0.0059 & 0.0339 \\
Sample: 1970-2001 & 0.9938 & 0.9660 \\
RMS & & \\
MAE & & \\
TIC & 2.1939 & 1.8973 \\
BP & 2.7171 & 1.3801 \\
VP & & \\
CP & 0.1932 & 0.1640 \\
\hline
\end{tabular}

Note: In-Sample Forecast estimates generated with EvIEWs 5.0.

\section{Desarrollo}


break could be rejected. The Chow breakpoint tests (available upon request) suggested that the hypothesis could not be rejected for the crisis years of 1973, 1975, and 1982.

The EC models were also used to track the historical data on labor productivity growth in Chile. Table 4 below presents selected Theil inequality coefficients obtained from the historical simulations of the productivity growth equations. The Theil inequality coefficient measures the root-mean-square (RMS) error in relative terms; i.e., it is a measure of the deviation between the simulated values of the variable and its actual value scaled so that it falls between 0 and 1 . If the Theil coefficient is 1 then the predictive performance of the model is at its worst, while if it is equal to zero it is perfect. In general, the predictive power of the model is considered to be quite good if the coefficient is below 0.3 (see Theil, 1966). As can be seen from Table 4, the coefficients are well below the threshold value suggested by Theil, e.g., 0.2108 and 0.2015 for equations (2) and (4), respectively.

The Theil coefficients can also be decomposed into three major components: the bias, variance, and covariance terms. The bias proportion measures the extent to which the average value of the simulated series deviates from its historical value, while the variance and covariance ratios measure, respectively, the capacity of the model to simulate the historical variability in the variable, and its ability to replicate the remaining error after the average deviations have been accounted for. Ideally, the bias and variance components should equal zero, while the covariance proportion should equal one. Table 4 shows that all of these ratios are close to their optimum values. Sensitivity analysis on the coefficients also revealed that changes in the initial or final period did not alter the predictive power of the selected models (or, for that matter, any of the models run in this study).

Figure 1, corresponding to equation (4) in Table 3, provides visual evidence of the models' ability to track the turning points in the actual series. (PGR) refers to the actual

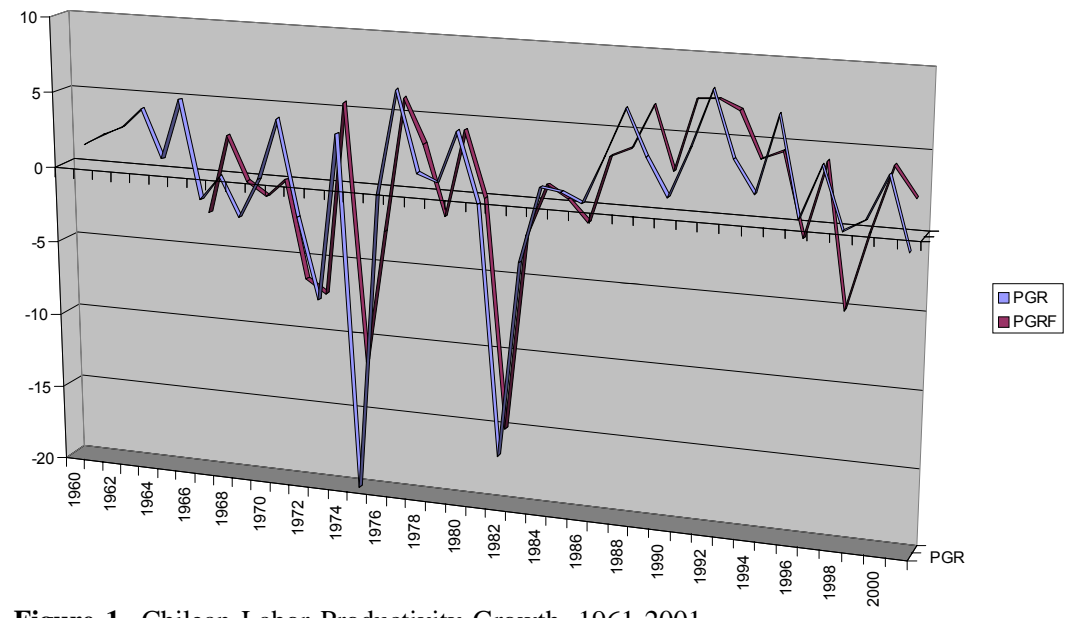

Figure 1. Chilean Labor Productivity Growth, 1961-2001. 
series and (PGRF) denotes the in-sample fit. It also highlights the Chilean economy's highly variable and, at best, modest increase in labor productivity for the period under review. Part of the explanation for this lackluster performance resides in the country's tumultuous economic and political history, particularly during the seventies and early eighties. However, beginning in 1985 and following the return to democratic rule, there is evidence of a modest upward trend in labor productivity, although it is too early to tell whether this represents a permanent break with the past.

\section{Conclusion}

This paper has analyzed the impact of FDI flows on labor productivity growth in one of Latin America's more economically successful countries, Chile. Several major findings were presented. First, the evidence for Chile suggests that although FDI flows were substantial during the nineties, particularly in relation to domestic capital formation, there was also a substantial increase in the reverse flow of profits and dividends that could offset the future contribution of FDI to financing capital formation. Second, the econometric results suggest that the variables included in the production function have a stable and non-spurious relationship that keeps them in proportion to one another in the long run, even though each variable in level form has a stochastic trend. The ECM estimates show that (lagged) FDI flows had a positive and significant effect on labor productivity growth during the 1960-2001 period, and the interactive term suggests that the effect was stronger during 1996-2001. The latter result is important because it suggests that the channeling of FDI to so-called greenfield investments, as well as recent acquisitions of existing firms in energy, telecommunications, and financial services, has had a positive effect on labor productivity growth. The lagged public investment variable, as well as outward-oriented policies and economic crises (captured by dummies) were also found to have the expected sign and be statistically significant. The EC terms are negative and statistically significant, suggesting that contemporaneous shocks to the long-run labor productivity relationship are corrected in subsequent periods. Finally, Theil inequality coefficients indicate that the EC models are able to track the historical data on labor productivity growth rather well.

From a policy standpoint, the Chilean economy may have much to gain by attracting FDI flows, particularly if they are channeled to greenfield investments where the (longrun) positive spillover effects associated with FDI in the form of intangibles such as the transfer of technology and managerial know-how are greatest. On the other hand, policies that attract FDI on the basis of overly generous subsidies, lavish tax concessions, and few, if any, restrictions on profit and dividend remittances should be avoided. The evidence showed that TNCs' remittances of profits and dividends from the country have grown substantially since 1992, and that once these reverse flows are subtracted from the gross inflows of FDI, the contribution of FDI to the financing of private capital formation in

\section{DeSarrollo}


Chile is reduced significantly. In light of this, an important avenue for future empirical research is to determine whether FDI flows continue to exert a positive and significant effect on labor productivity growth in Chile in the presence of substantial reverse flows of profits and dividends.

\section{Data Appendix}

The (annual) economic data used in this study were obtained from official government sources such as the Instituto Nacional de Estadísticas (various issues) and the Banco Central de Chile, Memoria Anual (various issues). ${ }^{12}$ Public and private investment data for Chile were obtained from the International Finance Corporation, Trends in Private Investment in Developing Countries: Statistics for 1970-2000 (Table C1, 2001) and ECLAC (2002). In the economic development literature proxies are often used for variables such as the labor force and/or the stocks of private domestic capital and FDI (see Aschauer, 1990; Cardoso, 1993; Lin, 1994; Nazmi and Ramirez, 1997; and Ram and Zhang, 2002). For example, population data is used instead of labor force data, or investment data (as a proportion of GDP) is substituted for capital stock data. However, the use of these proxies imposes unduly restrictive assumptions (e.g., such as a fixed capital-output ratio) or unrealistic assumptions (a constant labor force participation rate) that generate both wrongly specified relationships and significant measurement errors (see Alexander, 1994). In the case of Chile we are fortunate to have a sufficiently long (and official) time series (annual) data set for private investment, public investment, and FDI flows extending back to 1960 . Using a perpetual inventory method, capital stock data was generated for the variables in question. Initial stocks of private (public) and foreign capital were estimated by aggregating over five years of gross investment (1956-1960), assuming an estimate of the rate of depreciation of 5 percent. To ensure the robustness of the results, other estimates of the rate of depreciation were used (10 percent), as well as different estimates of the initial capital stock (e.g., summing over 4 and 6 years), but the results were not altered significantly. Finally, Chile's National Institute of Statistics (INE) has also published official data on the labor force for the period under review.

12 Investment data was cross $\sim$ checked with that found in the International Finance Corporation, Trends in Private Investment in Developing Countries: Statistics for 1970 2000 (2001) and no significant differences were discerned.

\section{DeSarrortollo}




\section{References}

Agosin, Manuel R. (editor), Foreign Direct Investment in Latin America, Washington, InterAmerican Development Bank, 1995.

Alexander, W. Robert J., "The Investment-output Ratio in Growth Regressions", en Applied Economic Letters, núm. 1, 1994, pp. 74-76.

Aschauer, David A., "Public Investment and Productivity Growth in the Group of Seven", en Economic Perspectives, núm. 13, septiembre/ octubre, 1989, pp.17-25,

, "Is Government Spending Stimulative?", en Contemporary Economic Policy, núm. 8, octubre de 1990, pp. 30-46.

Bosworth, Barry P. y Susan M.Collins, "Capital Flows to Developing Economies: Implications for Savings and Investment", en Brookings Papers on Economic Activity, núm. 1, 1999, pp. 143-180.

Caceres, Luis R., "La relación de largo plazo entre el ahorro y la inversion en la América Latina", en El Trimestre Económico, vol. LXIv, núm. 3, julioseptiembre de 1997, pp. 305-317.

Cardoso, Eliana, "Private Investment in Latin America", en Economic Development and Cultural Change, núm. 41, julio de 1993, pp. 833-848.

Charemza, W.W. y D.F. Deadman, New Directions in Econometric Practice: General to Specific Modelling, Cointegration and VectorAutoregression, Cheltenham, Edward Elgar Publishers, 1997.

Cruz, Bruno de O. y J.R. Teixeira, "The Impact of Public Investment on Private Investment in Brazil, 1947-1990”, en CEPAL Review, núm. 67, abril de 1999, pp. 75-84.

Cypher, James M. y James L. Dietz, The Process of Economic Development, Nueva York, Routledge, 1997.

De Mello, Jr. Luiz R., "Foreign Direct Investment in Developing Countries and Growth: A Selective Survey", en Journal of Development Studies, vol. 34, núm. 1, octubre de 1997, pp. 1-34.

Dickey, D. y W. Fuller, "Likelihood Ratio Statistics for Autoregressive Time Series with a Unit Root", en Econometrica, junio de 1979, pp. 1057-1072

ECLAC, Foreign Investment in Latin America and the Caribbean, 2000 Report, Santiago de Chile, United Nations, 2001.

- Foreign Investment in Latin America and the Caribbean, 1999 Report, Santiago de Chile, United Nations, 2000

— La inversion extranjera en América Latina y el Caribe, Santiago de Chile, United Nations, 1998.
- Economic Survey of Latin America and the Caribbean, 2000-2001, Santiago de Chile, United Nations, 2002.

Engle, R.F. y C.W.J. Granger, "Cointegration and Error Correction: Representation, Estimation, and Testing", en Econometrica, núm. 55, marzo de 1987, pp. 251-76.

Evenhart Stephen S. y Mariusz A. Sumlinski, Trends in Private Investment in Developing Nations: Statistics for 1970-2000, Washington, International Finance Corporation, 2001.

Ffrench-Davis, R. y O. Munoz, "Economic and Political Instability in Chile", en Simon Teitel (editor), In Towards a New Development Strategy for Latin America, Washington, InterAmerican Development Bank, 1992.

Foster, Andrew D. y M.R. Rosenzweig, "Learning by Doing and Learning from Others: Human Capital and Technical Change in Agriculture", en Journal of Political Economy, núm. 103, diciembre de 1995, pp. 1176-1209.

Granger, C.W.J. y P. Newbold, "Spurious Regression in Econometrics" en Journal of Econometrics, núm. 2, 1974, pp. 111-120.

Green, Joshua y Delano Villanueva, "Private Investment in Developing Countries: An Empirical Analysis", en IMF Staff Papers, vol. 38, núm. 1, marzo de 1991, pp. 33-58.

Harris, Richard, Using Cointegration Analysis in Econometric Modelling, Nueva York, PrenticeHall, 1995.

Johansen, Soren, "Statistical Analysis of Cointegrating Vectors", en Journal of Economic Dynamics and Control, núm. 12, junio/septiembre de 1988, pp. 231-254.

Johansen, Soren y K. Juselius, "Maximum Likelihood Estimation and Inference on Cointegration with Applications to the Demand for Money", en Oxford Bulletin of Economics and Statistics, núm. 52, mayo de 1990, pp. 169-210.

Lin, A. y Y. Steven, "Government Spending and Economic Growth", en Applied Economics, núm. 26, 1994, pp. 83-84.

Meller, Patricio, "Review of the Chilean Privatization Experience", en The Quarterly Review of Economics and Finance, núm. 33, 1993, pp. 95-112.

Nazmi, Nader y M.D. Ramirez, "Public and Private Investment and Economic Growth in Mexico", en Contemporary Economic Policy, núm. 15, enero de 1997, pp. 65-75.

Nelson, C. y C. Plosser, "Trends and Random Walks in Macroeconomic Time Series: Some Empirical 
Evidence and Implications", en Journal of Monetary Economics, núm. 10, 1982, pp. 139-162.

Phillips, P.C.B. y P. Perron, "Testing for a Unit Root in Time Series Regressions", en Biometrika, núm. 75, junio de 1988, pp. 335-346.

Plasschaert, S. (editor), Transnational Corporations: Transfer Pricing and Taxation, Londres, Routledge, 1994.

Ram, Rati y K.H. Zhang, "Foreign Direct Investment and Economic Growth: Evidence from Cross Country Data for the 1990s", en Economic Development and Cultural Change, núm. 51, octubre de 2002, pp. 205-215.

Ramirez, Miguel D., "Public Capital Formation and Labor Productivity Growth in Chile", en Contemporary Economic Policy, núm. 18, abril de 2000, pp. 159-169.
Roubini, N. y Sala-i-Martin, "Financial Repression and Economic Growth", en Journal of Development Economics, núm. 39, 1992, pp. 5-30.

Sánchez-Robles, Blanca, "Financial Efficiency and Economic Growth: The Case of Spain", en Atlantic Economic Journal, núm. 3, noviembre de 1997, pp. 333-351.

Theil, H., Applied Economic Forecasting, Amsterdam, North-Holland, 1996.

United Nations, World Investment Report 1998, Trends and Determinants, Switzerland United Nations, 1999.

Zhang, Kevin H., "What Attracts Foreign Corporations to China?", en Contemporary Economic Policy, núm. 19, julio de 2001, pp. 336-346.

\section{DeSarrrollo}

